\title{
Indledning tema 1: Spil i undervisningen
}

\section{Steffen Löfvall}

Chefkonsulent

Dekansekretariatet for uddannelse

Copenhagen Business School

sl.edu@cbs.dk



\section{Michael Pedersen}

Specialkonsulent

Akademisk IT

Roskilde Universitet

micp@ruc.dk

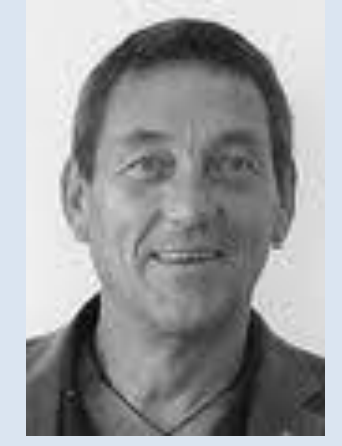

Kan spil bruges i undervisningen som andet end et underholdende pusterum for studerende og underviser i et ellers intenst læringsforløb? Kan brugen af spil være en seriøs læringsaktivitet på linie med andre anerkendte læringsaktiviteter? Kan de strategiske, kreative og sociale elementer, der ofte er inkorporeret 
i et moderne spil udnyttes til at gøre læreprocesser bedre, mere varierede, engagerende?

Brug af spil i undervisningen kan være en stærk ressource for underviseren, når der skal tænkes i nye undervisningsformer, nye veje til at nå de undervisningsmæssige mål og måder til at øge de studerendes engagement og motivation.

Anvendelse af læringsspil i undervisningen synes at motivere studerende til at tilegne sig ny faglig viden på en anden måde end de undervisningsformer, der oftest praktiseres på videregående uddannelser.

Derfor er det nærliggende at spørge, om det er muligt og hvordan det er muligt, at bruge de fascinerende og engagererende elementer fra "spillet" $\mathrm{i}$ undervisningssituationen.

I dette delnummer af Læring Og Medier (LOM) er der 4 bidrag, som på hver deres måde taget fat disse spørgsmål og problemstillinger mht. brug af spil i undervisningen. Fælles for alle artikler er, at de har valgt at tage brugen af spil i undervisningen alvorligt, og at de ser "spillet" som et interessant og værdifuldt didaktisk redskab.

Artiklen "Spilscenarier i undervisningen præsentation af en didaktisk model" af Thorkild Hanghøj præsenterer en didaktisk model. Modellen opererer med fire domæner: Fagdomænet, scenariedomænet, det pædagogiske domæne og hverdagsdomænet. Forfatteren mener, at modellen "både kan bruges deskriptivt til at forstå, hvordan spilforløb udfoldes som en relation mellem de fire domæner, og bruges præskriptivt som redskab til at integrere og redesigne den didaktiske brug af spilscenarier i forhold til bestemte læringsmål." Det er forfatterens tese, at 
"meningsfuld brug af spil i høj grad afhænger af, hvordan man som underviser formår at koble de fire forskellige domæner..."

Som grundlag for at illustrere modellens anvendelsesmuligheder, gennemgås to typer at spilbaserede undervisningsforløb.

\section{Artiklen "Refitting existing simulations to meet with new learning objectives - from supply chain} management to virtual collaboration" af Timo Lainema, Thomas Duus Henriksen, Eeli Saarinen rejser forfatterne spørgsmålet om, hvordan spil kan inddrages i seriøse læringsaktiviteter. Udgangspunktet er ikke at skabe nye spil men at analysere og diskutere, "how existing learning games can be reconfigured didactically to meet with more diverse learning objectives, as well as to encourage university teachers to think out of the box...".

I følge forfatterene er det vigtigere at fokusere på "the planning on how the actual game or simulation is applied within the particualr setting" end at fokusere på de konkrete læringsaktiviteter, som spillet tilbyder. Og de ønsker, at "... exemplify how the simulation gaming artefact and its structuration is open for examination, rather than being fixed."

\section{Artiklen "Design af computerspil i undervisningen: Fra} indfødt i spilverdenen til reflekteret designer" af Gunver Majgaard tager udgangspunkt i et konkret undervisningsforløb med første semester studerende fra uddannelsen lærings- og oplevelsesteknologi, hvor der lægges vægt på at inddrage de studerendes egne erfaringer med at spille spil i den konkrete lærings- og undervisningsproces.

Der introduceres konkrete eksempler på spil, som de 
studerende har udviklet, og det diskuteres hvordan og hvad, de studerende har lært i designprocessen.

Sammenfattende redegør artiklen for disse studerendes første rejse fra indfødte i spilverdenen til reflekterende designere. "For at kunne foretage en transformation fra spillerrollen til spildesignerrollen var de studerende nødt til at gå fra at være "indfødte" i spilverdenen til at kunne lægge den distance til spillerrollen. De var nødt til at kunne reflektere over, hvad spil er, hvad der gør dem interessante, hvordan de er opbygget og i sidste ende selv udvikle prototyper."

Artiklen viser desuden, at der er et meget dynamisk frugtbart forhold mellem det at spille spil og det at designe spil.

\section{I artiklen "Spildesign i Serious Games - en didaktisk}

udfordring?" diskuterer forfatterne Niels Henrik Helms og Jess Uhre Rahbek med udgangspunkt i analyse af brugen af et konkret spil, hvordan man sikrer, at spil, som skal være lærende, også lever op til kravet om at være underholdende. Spillet er nødt til både at opfylde de krav, som "spillere" stiller til spillets spændig og udfordringer, samtidig med at det reelt rummer nogle læringspotentialer.

Forfatterne rejser spørgsmålet om, hvordan man kan fastholde den særlige autencitet, når man ikke længere spiller for at spille, men for at lære? Og deres svar i artiklen er, at det er "... nødvendigt at arbejde flerfagligt. Hvis der er et dårligt spildesign, så vil ingen gide bruge spillet. Hvis der er et dårligt didaktisk design, så vil der måske nok blive spillet, men de ønskede læringsmål vil ikke blive indfriet. "

De konkluderer, at skal der udvikles læringsspil "... er der behov for både didaktiske og spildesign kompetencer, og ikke alene er der altså behov for, at disse kompetencer er 
til stede, men at de fungerer i et dynamisk samspil for at udvikle et godt gameplay, hvor læringen er integreret, så læringen sker i forbindelse med spillet - og ikke som kunstige afbrydelser." 